\title{
Areal Changes of Lentic Water Bodies Within an Agricultural Basin of the Argentinean Pampas. Disentangling Land Management from Climatic Causes
}

\author{
Gisel Carolina Booman • Mirta Calandroni • \\ Pedro Laterra · Fabián Cabria · Oscar Iribarne • \\ Pablo Vázquez
}

Received: 25 July 2011/Accepted: 20 August 2012/Published online: 19 September 2012

(C) Springer Science+Business Media, LLC 2012

\begin{abstract}
Wetland loss is a frequent concern for the environmental management of rural landscapes, but poor disentanglement between climatic and land management causes frequently constrains both proper diagnoses and planning. The aim of this study is to address areal changes induced by non-climatic factors on lentic water bodies (LWB) within an agricultural basin of the Argentinean Pampas, and the human activities that might be involved. The LWB of the Mar Chiquita basin (Buenos Aires province, Argentina) were mapped using Landsat images from 1998-2008 and then corrected for precipitation variability by considering the regional hydrological status on each date. LWB areal changes were statistically and spatially analyzed in relation to land use changes, channelization of streams, and drainage of small SWB in the catchment areas. We found that $12 \%$ of the total LWB in the basin had changed $(P<0.05)$ due to non-climatic causes. During the evaluated decade, $30 \%$ of the LWB that changed size had decreased while $70 \%$ showed steady increases in area. The number of altered LWB within watersheds lineally increased or decreased according to the proportion of grasslands replaced by sown pastures, or
\end{abstract}

\section{G. C. Booman $(\bowtie) \cdot$ O. Iribarne}

Departamento de Biología, Facultad de Ciencias Exactas, Universidad Nacional de Mar del Plata, Dean Funes 3350, 7600

Mar del Plata, Buenos Aires, Argentina

e-mail: gcbooman@yahoo.com

M. Calandroni - P. Laterra - F. Cabria

Facultad de Ciencias Agrarias, Universidad Nacional de Mar del Plata, National Route 226 Km. 73.5, 7620 Balcarce, Buenos

Aires, Argentina

P. Vázquez

EEA Guillermo Covas Anguil, Instituto Nacional de Tecnología Agropecuaria, National Route 5 Km. 580, 6326 Anguil,

La Pampa, Argentina the proportion of sown pastures replaced by crop fields, respectively. Drainage and channelization do not appear to be related to the alteration of LWB; however some of these hydrologic modifications may predate 1998, and thus earlier effects cannot be discarded. This study shows that largescale changes in land cover (e.g., grasslands reduction) can cause a noticeable loss of hydrologic regulation at the catchment scale within a decade.

Keywords Lentic water bodies - Agricultural intensification - Watersheds · Land management . Channelization - Wetland drainage

\section{Introduction}

The intensification and expansion of the agricultural frontier that has taken place in recent decades in different regions of the world (Liu and others 2005; Viglizzo and others 2006) has been frequently linked to the deterioration and even the loss of wetland ecosystems (WCMC 1992; Gerakis and Kalburtji 1998; Quirós and others 2006; Zhang and others 2010). Wetlands support biodiversity and ecosystem services that should be protected, and therefore there is also an effort to create wetlands (Keddy 2010). Although wetland loss is a frequent concern for the environmental management of rural landscapes, poor disentanglement of climatic and land management causes frequently constrains both proper diagnoses and planning.

The main conditioning factor for the structural and functional properties of wetland ecosystems is the hydrological regime (Mitsch and Gosselink 2000). In this sense, the human modification of hydrological regimes through landscape changes is probably a main threat to wetland ecosystems. 
In Argentina, the wetland area of the Pampas Region is extensive and includes littoral zones of shallow lakes, marshes, lagoons and flood meadows, as well as the large Mar Chiquita coastal lagoon $\left(37^{\circ} 43^{\prime} \mathrm{S} ; 57^{\circ} 24^{\prime} \mathrm{W}\right)$ and tidal marshes on the Atlantic coast. In recent decades, this region has experienced intensification of agriculture that has triggered major structural and functional changes to native vegetation (Viglizzo and others 2006). However, the relationship between land use and hydrology is poorly known (Jobbágy 2011). Also, there is some evidence that the drainage of natural wetlands, especially the smaller ones, along with channelization works aimed to increase the productive land surface, are leading to a decrease in wetlands abundance and size (Quirós and others 2006). Thus, there is a need for comprehensive studies assessing the direct and indirect impacts of land management practices on the hydrology of the watersheds, at the landscape scale.

Wetlands delineation through image processing is complex and requires detailed soil information, often unavailable (e.g., Kandus and others 2008). Here we adopt the term "lentic water bodies" (from now on, LWB) to refer to surfaces that are temporally or permanently covered by water and easily distinguished through image processing. These exclude areas of the landscape that are only occasionally flooded. Changes in the LWB areas could be used as a proxy to study potential impacts on wetlands. Under this framework, the aim of this study is to address areal changes in the surface of LWB that are not induced by climate variations, and the relationship with the human activities that could be affecting the hydrological dynamics of one of the main agricultural basins of the Argentinean Pampas.

\section{Materials and Methods}

\section{Study Area}

The Mar Chiquita's basin (Fig. 1), with approximately one million hectares, includes portions of the Flooding Pampas and Southern Pampas of Argentina (Soriano 1992). It combines the major regional land uses, including traditional agriculture in the process of increasing intensification and expansion, mixed agricultural-livestock systems and pure livestock systems in the lower fields. Intensive productions (horticulture, feedlots, and poultry) are less common and located in areas close to cities. The climate is sub humid-humid temperate, with an average rainfall of $1,120 \mathrm{~mm}$. The hydrology is characterized by the presence of lowland streams, floodplains, permanent and intermittent shallow lakes, and larger wetlands like the Mar Chiquita coastal lagoon $\left(37^{\circ} 43^{\prime} \mathrm{S} ; 57^{\circ} 24^{\prime} \mathrm{W}\right.$; Fig. 1), a
MAB reserve (UNESCO) that acts as a sink for many of the streams in the basin that primarily originate in the hills of the Tandilia system.

\section{Image Classification and Processing}

In order to identify the LWB of Mar Chiquita basin, eighteen Landsat TM/ETM images covering the period 1998-2008 (Table 1) were georeferenced with an error of less than $0.02 \%$ and converted to reflectance according to Chander and others (2009) and the Landsat 7 Science Data Users Handbook (NASA 2009). The images were then processed according to the following equation: (b5 b3 $)+(\mathrm{b} 7-\mathrm{b} 3), \quad$ where $\quad$ b5 $=$ middle infrared $(1.55-1.75 \mu \mathrm{m}), \mathrm{b} 3=\operatorname{red}(0.63-0.69 \mu \mathrm{m})$ and $\mathrm{b} 7=$ middle infrared $(2.08-2.35 \mu \mathrm{m})$. Landsat bands 5 and 7 show absorbance peaks for photosynthetic active vegetation, while band 3 shows a reflectance peak for water. As a result, the b5 - b3 and b7 - b3 operations allow for the identification of waterlogged areas, which appear as negative values. The resultant layers were monitored through visual analysis based on randomly selected checkpoints in Landsat RGB compositions for each date, and high-resolution images available from Google Earth ${ }^{\mathrm{TM}}$ (http:// earth.google.com). Afterwards, the LWB were delineated considering areas frequently covered by water, by using ArcGIS 9.2. First, layers were re-classified considering water presence. Pixels with water were valued 1 , and 0 was assigned to the rest along the 18 layers. Second, layers were added into a new layer, where pixels with water in less than $15 \%$ of the dates were not considered to be part of a LWB. This threshold was the best suited for the study area in order to eliminate pixels only occasionally covered with water or misclassified due to spectral signature overlap between water and other coverages, while preserving areas that were almost certainly part of LWB. Then, a $3 \times 3$ pixel size-based filter was applied in order to remove areas regarded as noise according to the images resolution (Jensen and others 2001). The identified pixels were grouped by transforming the raster layers into shapefiles, obtaining 3,687 LWB larger than $8,100 \mathrm{~m}^{2}$. Finally, the area with water within each LWB was calculated for each date.

\section{Evaluation of Non-climatic Influences on Changes} in LWB Between 1998-2008

To identify patterns of hydrological changes in LWB as a result of land management practices, it is necessary to disentangle it from the climate or regional hydrology influences. To remove the effect of climate on the variations in the LWB areas, the area with surface water within each LWB at each date was relativized according to the 
Fig. 1 The Mar Chiquita basin (Buenos Aires province, Argentina), with its main streams and watersheds. The assigned watershed numbers are displayed in the map, as well as two of the largest wetlands of the basin: the Mar Chiquita coastal lagoon, and Los Talitas lagoon

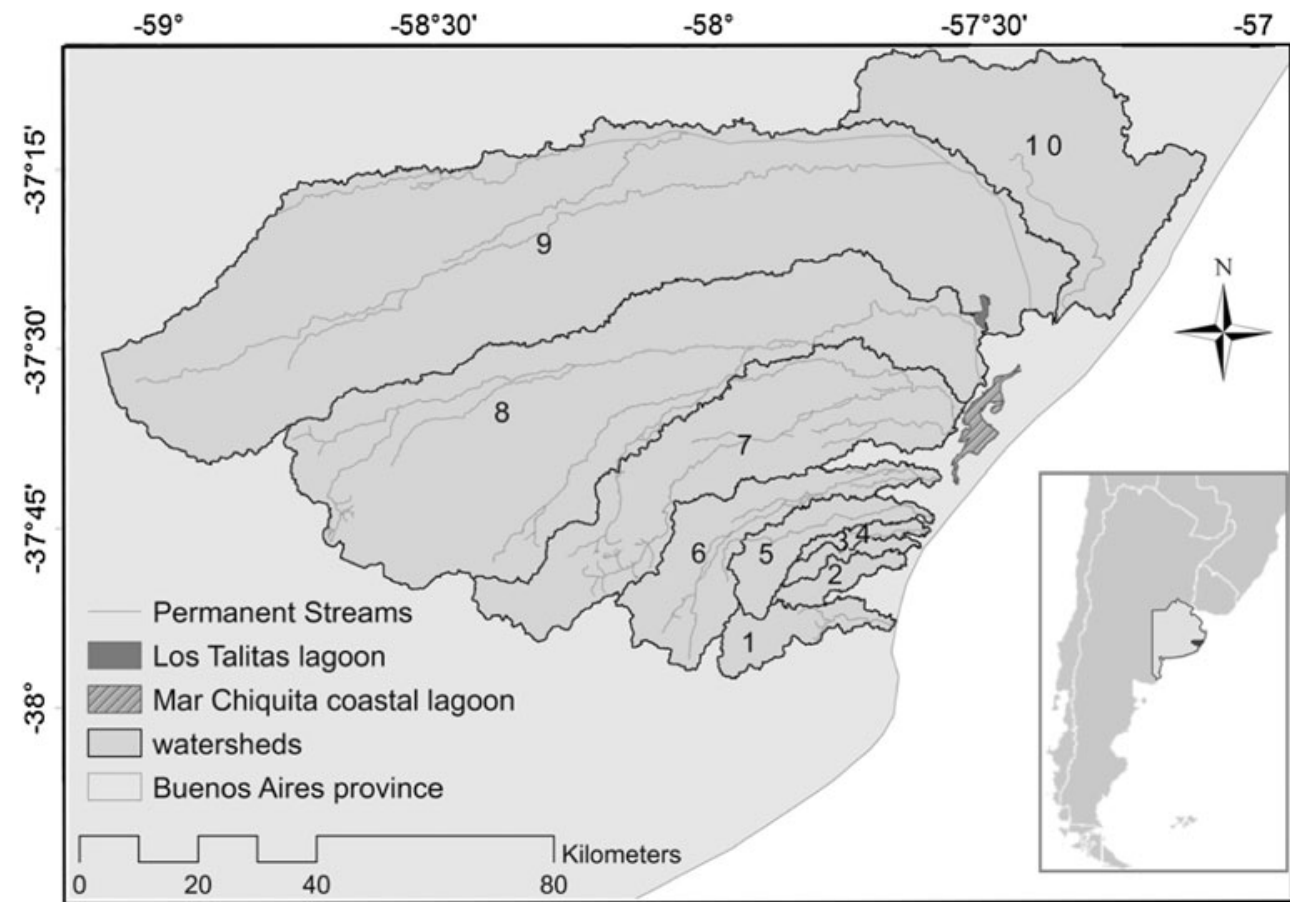

Table 1 Dates and sensor details for the eighteen landsat images used in the study

\begin{tabular}{llll}
\hline Year & Date & No & Landsat sensor \\
\hline 1998 & Aug-26 & 1 & TM \\
& Oct-29 & 2 & TM \\
1999 & Feb-18 & 3 & TM \\
& Oct-16 & 4 & TM \\
2000 & Jun-04 & 5 & ETM \\
2001 & Mar-19 & 6 & ETM \\
2002 & Oct-16 & 7 & ETM \\
& Mar-14 & 8 & ETM \\
2003 & Jan-20 & 9 & ETM \\
2004 & Mar-03 & 10 & TM \\
& Aug-10 & 11 & TM \\
2005 & Feb-02 & 12 & TM \\
& Oct-16 & 13 & TM \\
2006 & Feb-05 & 14 & TM \\
& Nov-20 & 15 & TM \\
2007 & Apr-13 & 16 & TM \\
2008 & Apr-29 & 17 & TM \\
& Nov-09 & 18 & TM \\
\hline \multirow{2}{*}{200} & & &
\end{tabular}

mean proportion of water in the corresponding watershed. This can be expressed as:

$\mathrm{LWB}_{\mathrm{ji}-\text { corr }}=\mathrm{LWB}_{\mathrm{ji}} / \mathrm{C}_{\mathrm{ni}}$

where $\mathrm{LWB}_{\mathrm{ji} \text {-corr }}$ is the $\mathrm{j}$ LWB area that was covered by water in the date $\mathrm{i}$, corrected by the hydrological conditions of the watershed on that date; $L_{W B}$ is the area with water of the $\mathrm{j}$ LWB at date $\mathrm{i}$, and $\mathrm{C}_{\mathrm{ni}}$ is the proportion of water cover in the corresponding watershed at date i.(i.e. the ratio between the sum of all the LWB areas in the corresponding watershed at date $\mathrm{i}$ and the watershed area).

Water cover in the watersheds was preferred instead of rainfall data as correction factor because LWB can receive water from surface runoff flows, as well as from subsurface and groundwater, and modeling the delay times of these flows is complex and requires large databases, not available for the area. Also, the availability of historical rainfall data is linked to the insufficient existence and operational capacity of the weather stations throughout the study region during the study period.

The watersheds were delineated using ArcHydro tools 9.2 and a DEM (digital elevation model) obtained from SRTM images with a $73.69 \mathrm{~m}^{2}$ resolution (Jarvis and others 2008). The DEM was previously corrected by eliminating sinks, woods, and by burning (i.e., enforcing) the streams digitized from Google Earth images, in order to enhance the ArcHydro performance. Next, the total surface water in each of the 18 dates was quantified within each watershed and made relative to the maximum surface water potential of the watershed within the 10-year period. In order to simplify the analysis, the number of $\mathrm{C}_{\mathrm{ni}}$ factors was reduced by grouping those watersheds with similar trends of change in the water surface, according to results from a cluster analysis (Euclidean distances).

Next, in order to analyze the variations in the areas of the corrected $\mathrm{LWB}_{\mathrm{ji} \text {-corr }}$ over time and identify those that significantly increased or decreased their area regardless of the weather, a regression analysis was applied to each identified LWB $(n=3,687)$. 
Linear regression models showed equal or better fit in all significant cases when compared to curve estimation regression models (logarithmic, logistic, power, exponential, quadratic, growth or inverse), so linear regression analysis was chosen to show the results. Regression slope $(\beta)$, significance $\left(P\right.$-value), and correlation coefficient $\left(\mathrm{R}^{2}\right)$ obtained from statistical analysis were incorporated into the attribute table of the LWB map in ArcGIS 9.2, in order to select and display only those LWB with significant regressions $(P<0.05)$ and distinguish between those with tendencies to increase $(\beta>0)$ or decrease $(\beta<0)$ in size.

The spatial distribution of LWB according to their tendencies of increase or decrease in area was analyzed by applying spatial statistics tools (ArcGIS 9.2, Spatial Analyst). Aiming to identify neighbor LWB with similar temporal patterns of area variation, a spatial analysis of clusters of multiple distances (Ripley's K function) was first performed to determine the optimal scale for the cluster analysis. Then, the resulting area was entered as a parameter to perform a Spatial Cluster and Outlier Analysis (Anselin's Local Morans I) on those LWB with regression fit. Finally, LWB with significant non-climatic changes in the areas during the study period were quantified within each watershed of the basin. Results are expressed as \% of decreasing or increasing LWB that are located within each watershed.

\section{Human Impacts on LWB}

\section{Land Use Changes}

In order to quantify the extent of agricultural expansion in the different watersheds of the basin, land use/land cover maps corresponding to the beginning and near the end of the study period (1998-2006; Zelaya and Maceira 2007) were analyzed and compared. In both maps, the total area devoted to crop fields, sown pastures, and seminatural grasslands plus old fields (from now on, "grasslands") within each watershed were quantified, and then the difference between both years for each land use was calculated. Also, to test the influence of some specific land use change patterns on the LWB hydrology, the total area of grasslands that was replaced exclusively by sown pastures and the total area of pastures that was replaced by crop fields from 1998 to 2006 were calculated within each watershed. All the areas were calculated by using math tools and zonal tools in the Spatial Analyst in ArcGIS 9.2. Finally, the areas of change or replacement were made relative to the watershed areas, obtaining percentage areas of change or replacement. These variables were then contrasted with the percentage of LWB that increased or decreased their area within the different watersheds between 1998 and 2006, by performing regression analysis.
To confirm that linear regression model assumptions were satisfied, variables were checked for normality (skewness and kurtosis values), and residuals were analyzed for homoscedasticity (q-q plots) and autocorrelation (DurbinWatson test).

\section{Channelization of Streams and Small Wetlands Drainage}

In order to quantify the intervention by channelization of watercourses in the basin, all the streams were digitized in Google Earth, identifying those portions where modification was obvious. The altered portions of streams in plain areas were easily distinguished in the images from those still unmodified. This was due to the contrast between the straight sections and the natural meanders, and the presence of mounds of bare soil on the banks as a result of excavations (see example in Fig. 2). Also, all the channels done outside the natural courses of streams were digitized. The gathered information was then exported to ArcGIS in order to calculate the total length $(\mathrm{km})$ of natural and channelized streams and extra-stream channels considering the terrain slopes. Additionally, all the small LWB that have been crossed by channels, but were initially excluded from the main analysis due to the resolution of the Landsat images (less than 8,100 $\mathrm{m}^{2}$ ) were identified in Google Earth and quantified in ArcGis. The results were then compared with the outcomes from "Evaluation of non-climatic influences on changes in LWB between 1998-2008" section by correlation analysis.

\section{Results}

Evaluation of Changes in the LWB of the Mar Chiquita Basin Between 1998-2008

According to cluster analysis performed over the variations in surface water trends along the 10-year period, watersheds felt into one of three different patterns: (1) watersheds 1 and 6; (2) watersheds 2-5; (3) watersheds 7-10 (Fig. 3).

From all the LWB mapped within the Mar Chiquita basin through Landsat images $(n=3,689)$, it was found that $12.14 \%(n=312)$ changed their area from 1998 to 2008, when excluding the effect of the regional hydrology $(P<0.05)$ (Fig. 4). A $30.45 \%(n=95)$ of these LWB showed a tendency towards reduction of the area. These LWB represent almost $23 \%$ (approx. 7,540 ha) of the total LWB area in the basin, and included two of the largest wetlands: Los Talitas $\left(37^{\circ} 28^{\prime} \mathrm{S} 57^{\circ} 23^{\prime} \mathrm{W}\right)$, with a mean area of 750 ha, and Mar Chiquita coastal lagoon $\left(37^{\circ} 43^{\prime} \mathrm{S}\right.$; $57^{\circ} 24^{\prime} \mathrm{W}$ ), which covers approximately 4,847 ha (Fig. 1). On the other hand, 217 LWB have incremented their 


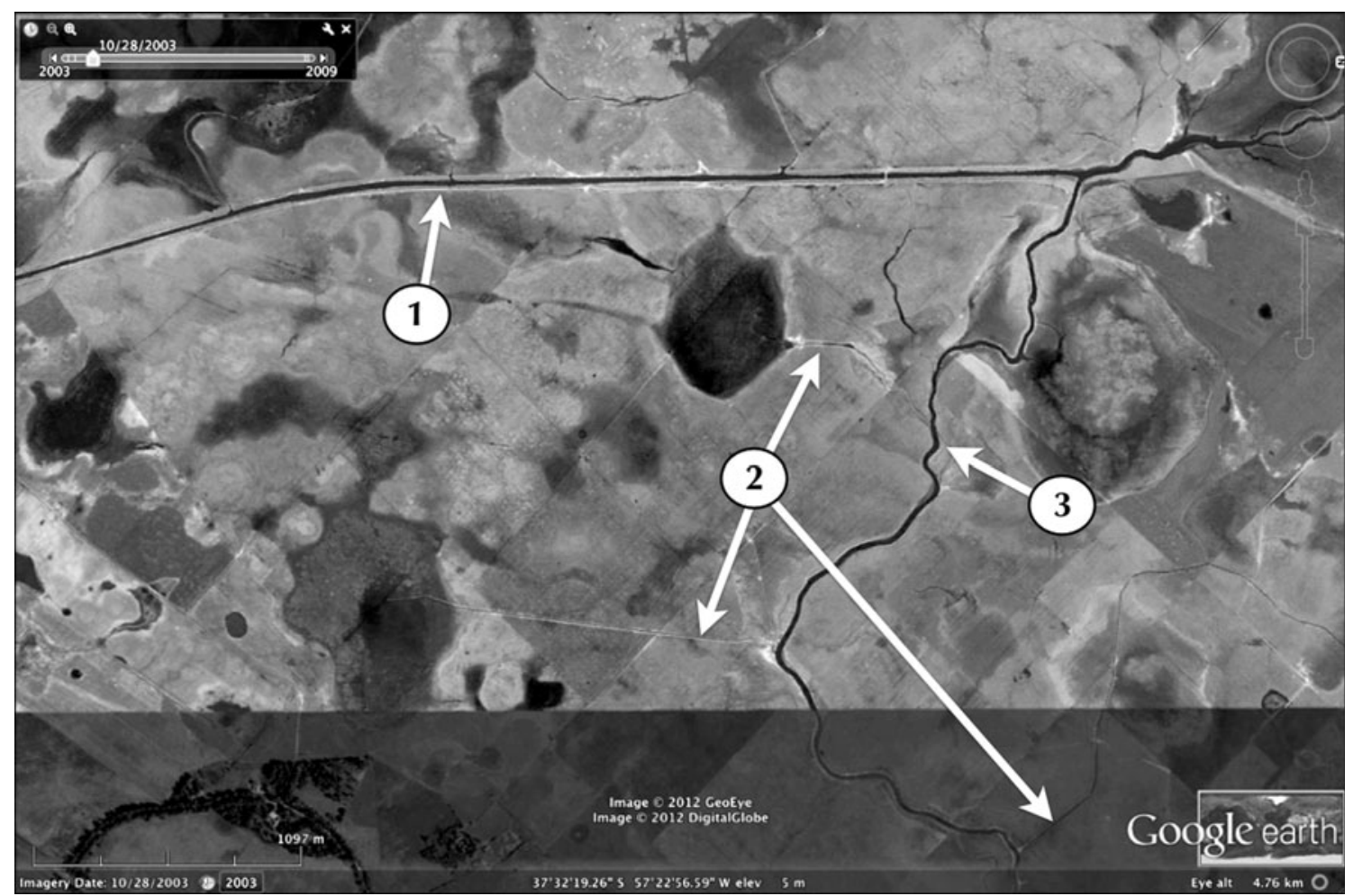

Fig. 2 Some examples of human interventions on the hydrology of the basin. 1 A channelized and rectified portion of a stream. 2 Artificial channels connecting LWB to a stream. 3 A natural portion of a stream, with its meanders

Fig. 3 Chronologic variations of $\mathrm{C}_{\mathrm{ni}}$ within 1998-2008 for the three groups of watersheds of the Mar Chiquita basin according to the cluster analysis results: 1 watersheds 1 and 6 ; 2 watersheds $2-5 ; 3$ watersheds $7-10 . \mathrm{C}_{\mathrm{ni}}$ is the mean proportion of the watershed area that was covered with water at each date, averaged between watersheds corresponding to the same cluster $( \pm \mathrm{SE})$

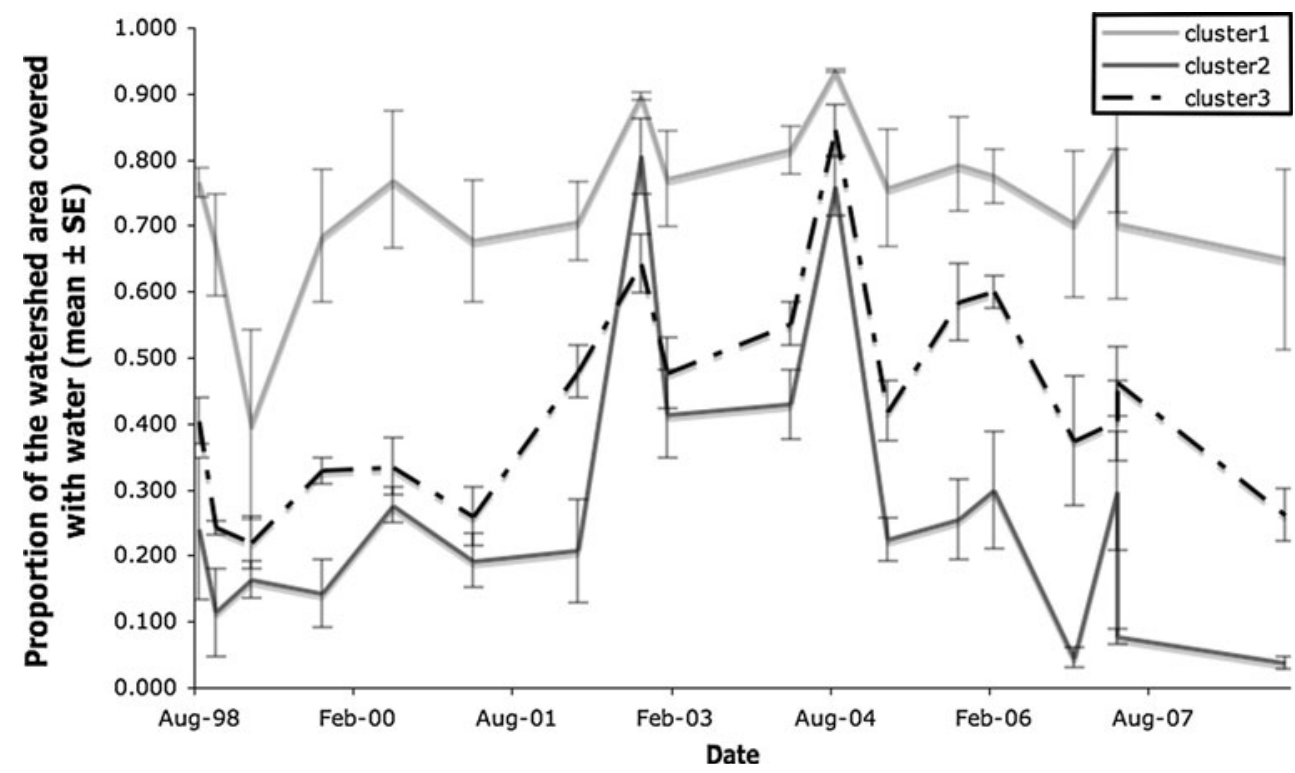

surface within the study period (Fig. 4). While more numerous, the LWB that enlarged their area only cover an area of approximately $7.9 \%$ (2629,88 ha) of the total LWB area in the basin.

The cluster analysis showed a main cluster of LWB with expanding surface area in the upper zone of the basin
$(P<0.01)$, most of them in the watershed number 10, and some at the north-east part of watershed number 9 . Also, some small clusters of nearby LWB with similar trends of decreasing area were identified in the western zones of watersheds 5, 6 and 8, and in the center zone of watershed 7. 
Fig. 4 Changes in LWB areas, after removing the climate variations. LWB that changed in size steadily and significantly $(P<0.05)$ over the last decade regardless the regional hydrology are shown colored depending on the slope of the linear regression (black area decreasing in time; grey area increasing in time). LWB that varied erratically or just following the hydrologic regimes (non significant regressions) are shown in white. The circular zoom is intended to show the presence of small LWB in the basin

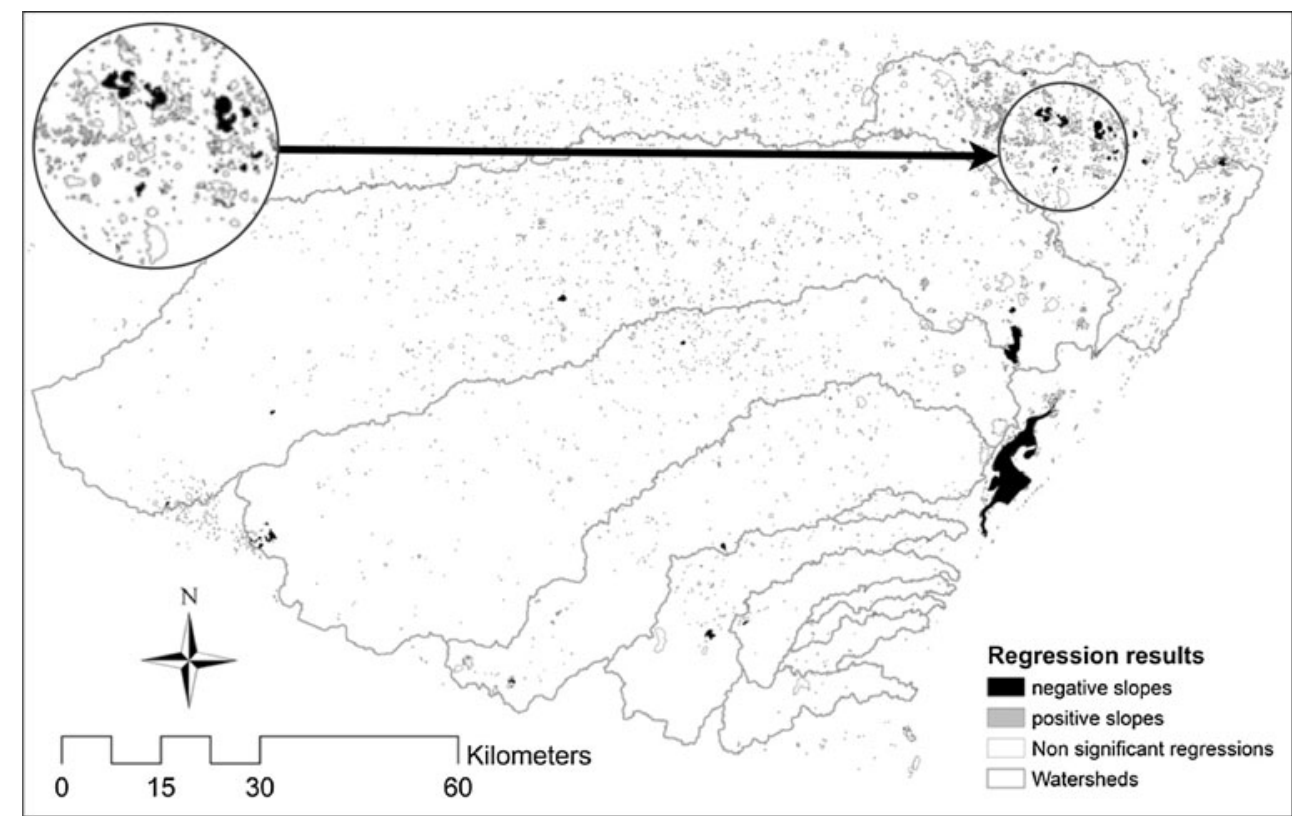

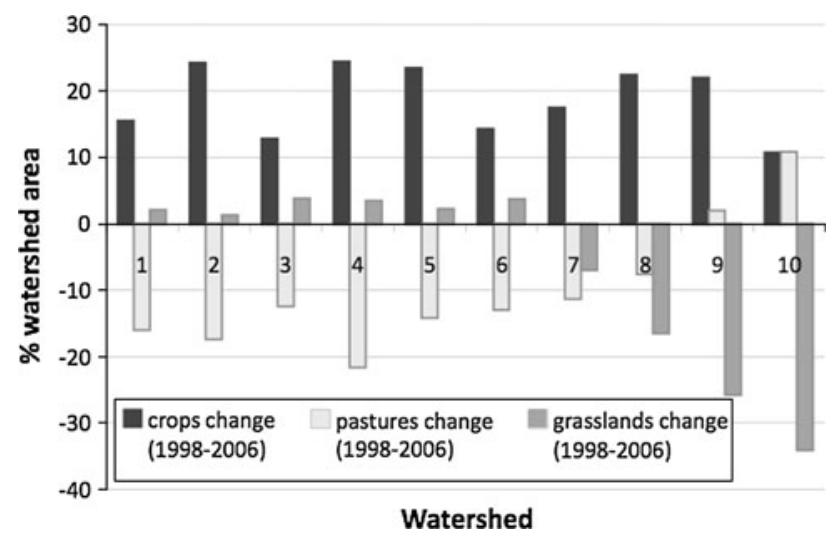

Fig. 5 Changes in three land uses within the watersheds of the Mar Chiquita basin between 1998 and 2006 (data from Zelaya and Maceira 2007). Positive values indicate an increment in the proportion of the watershed covered by crop fields, sown pastures or grasslands, whereas negative values indicate a decrease

\section{Human Impacts on LWB}

\section{Land Use Changes}

Within the study period, the area of crop fields increased in all the watersheds of the Mar Chiquita basin, expanding over more than $30 \%$ of the watershed area in some cases (Fig. 5). In contrast, sown pastures and specially grassland areas decreased dramatically in some watersheds (Fig. 5). The replacement of grasslands by sown pastures seems to explain much of the grassland area reduction, the same way as the reduction of sown pastures seems to be mostly explained by a replacement by crop fields (Fig. 6).

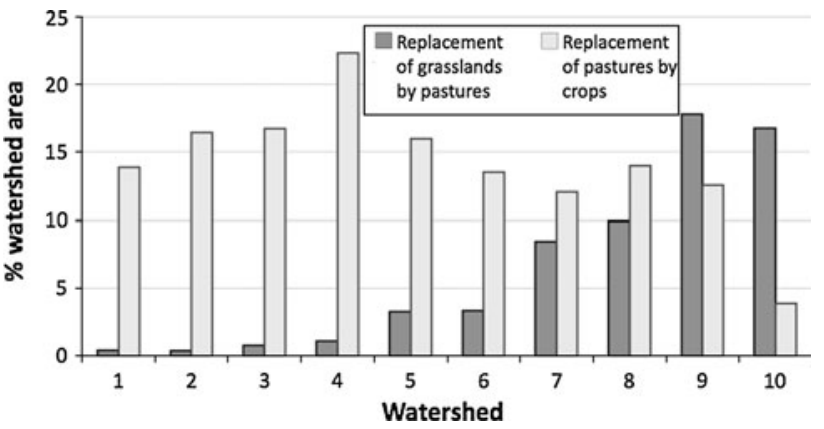

Fig. 6 Percentage areas of the watersheds where grasslands were replaced by sown pastures (light bars), or where sown pastures were replaced by crop fields (dark bars) between 1998 and 2006 (data from Zelaya and Maceira 2007)

According to regression analysis, the number of LWB that increased or decreased their area within the watersheds varied as a function of grassland loss $(P<0.001$; Fig. 7a) and sown pastures expansion between 1998 and 2008 $(P<0.001$; Fig. 7 b). Contrary to expectations, the distribution pattern of increasing or decreasing LWB was not related to the changes in the proportion of crop fields during the study period $(P>0.05$; Fig. $7 \mathrm{c})$.

As for the land use replacement variables, the distribution of the LWB that changed the area despite of climatic variations varied depending on the replacement of grasslands by sown pastures that took place between 1998 and 2006 in the different watersheds $(P<0.001$; Fig. 8a). Also, some part of the variability in the distribution of these LWB was explained by the replacement of sown pastures by crop fields $(P<0.05$; Fig. $8 b)$. 


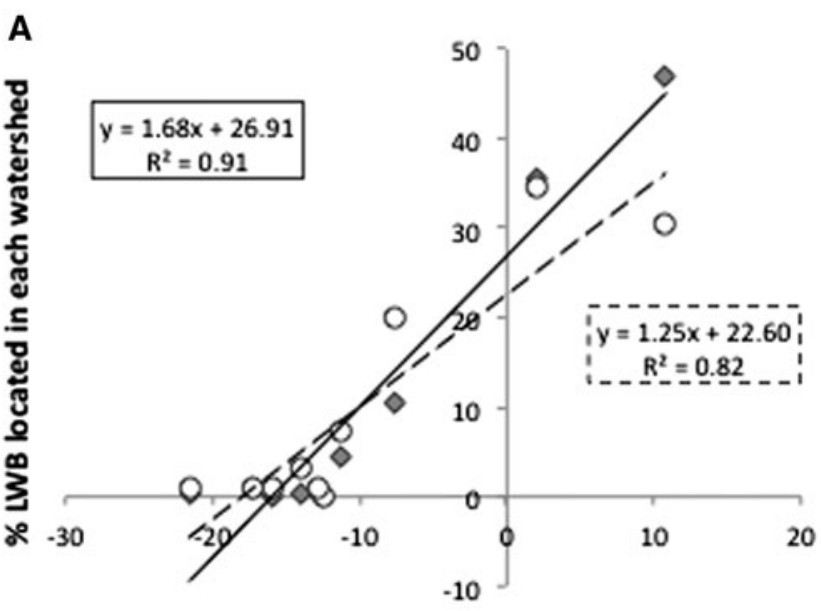

Pasture area change ( $\%$ subwatershed area)

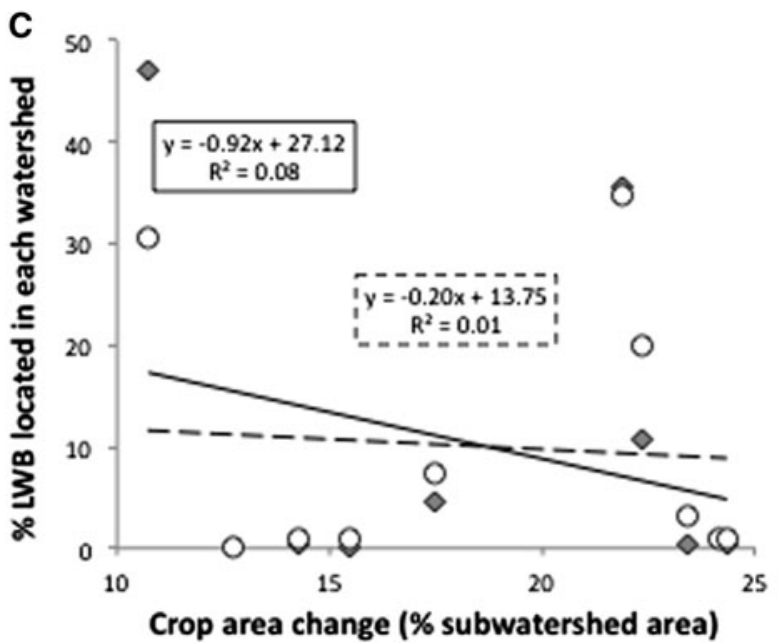

Fig. 7 Scatterplots showing the percentage of LWB located in each watershed that decreased or increased their area as a function of changes in the area of sown pastures (a), grasslands (b), or crop fields (c) between 1998 and 2006

\section{Channelization of Streams and Small LWB Drainage}

At least $17 \%$ of streams (315 linear $\mathrm{km}$ ) in the basin have been channelized to date. This is conservative given that only the channelized portions that showed robust evidence of human disturbance on the natural watercourses (e.g., presence of mounds in the banks as a product of excavations or water course rectifications) were considered. Channelization outside the natural waterways totaled 371 linear $\mathrm{km}$, affecting at least 199 small LWB (with areas smaller than $8,100 \mathrm{~m}^{2}$ ), currently traversed by such works (Fig. 9), presumably intended to increase the productive area through drainage. $90 \%$ of the stream channels, as well as $93 \%$ of the channelization was done outside the natural watercourses, and $83 \%$ of the small LWB crossed by canals are located within watersheds 7,8 and 9, which make up the majority of the drainage area of the Mar Chiquita coastal lagoon. In watershed number 10 , no

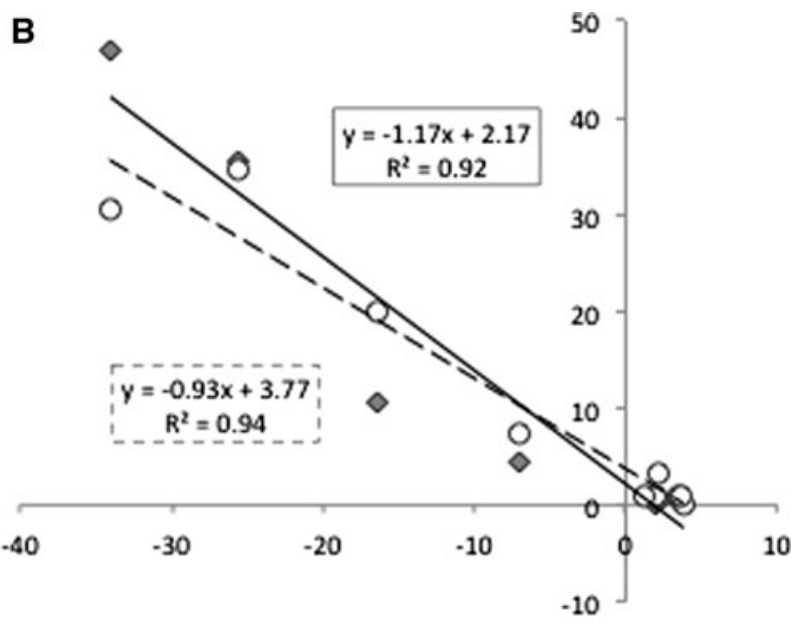

Grassland area change (\% subwatershed area)

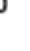

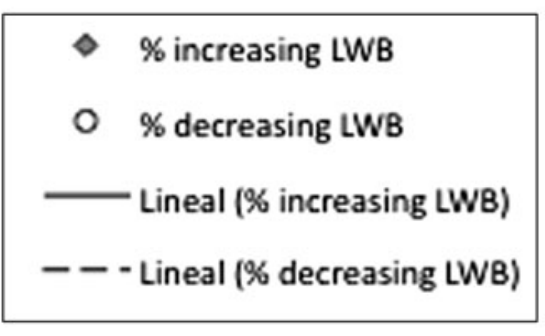



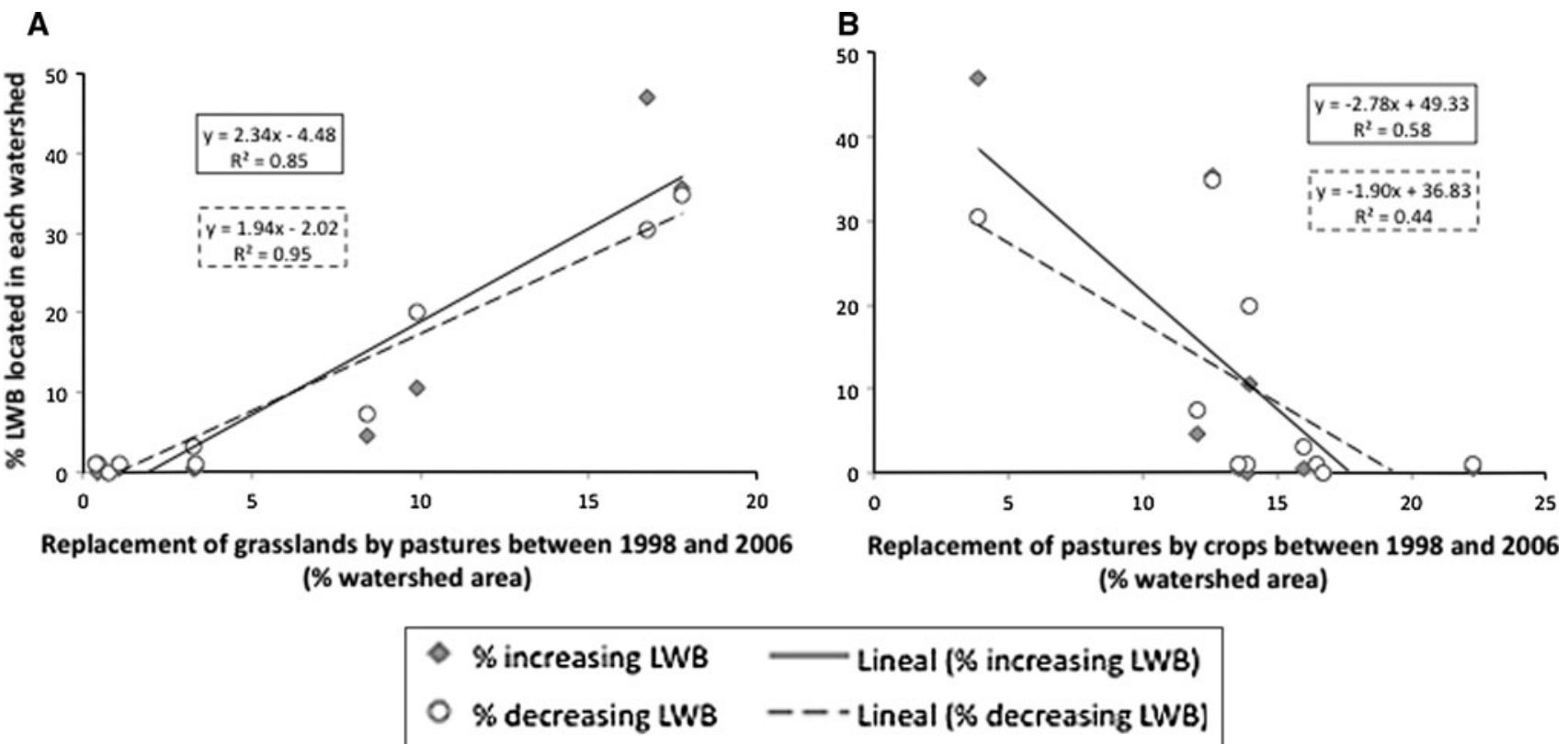

Fig. 8 Scatterplots showing the percentage of LWB located in each watershed that decreased or increased their area as a function of the percentage area of the watersheds where grasslands were replaced by

sown pastures (a), or pastures were replaced by crop fields (b), between 1998 and 2006
Fig. 9 Map showing the channelization works and the small LWB affected in the Mar Chiquita basin, to date

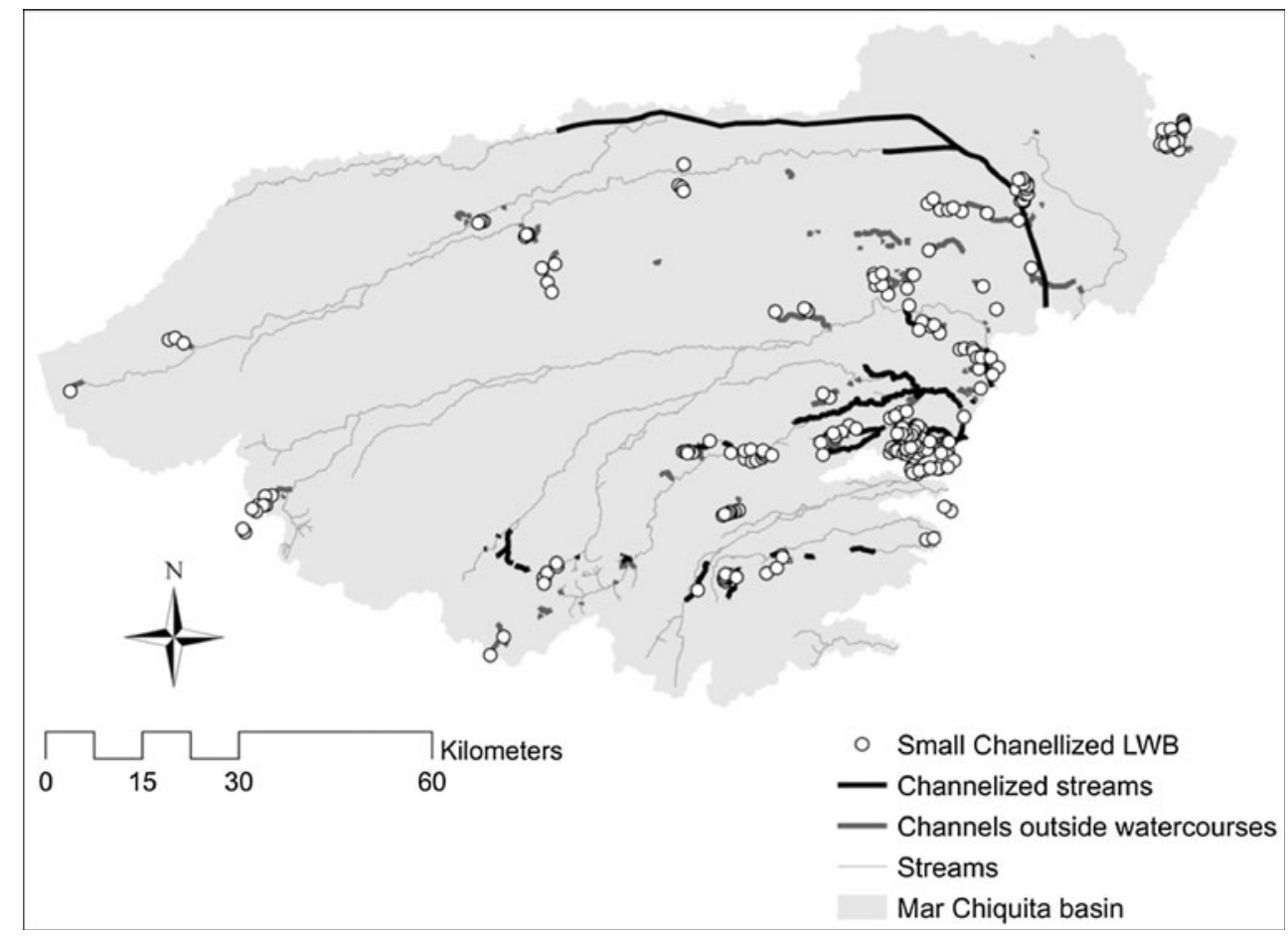

wetlands is usually accompanied by the loss of ecosystem services, including flood abatement, water supply, water quality improvement and carbon sequestration (Zedler and Kercher 2005). Wetlands are mainly conditioned by the hydrological regime (Mitsch and Gosselink 2000). Therefore, it is necessary to discriminate and monitor the changes in the hydrology that are driven by land management practices from those just reflecting climatic trends and fluctuations. Here we presented a simple methodology specially designed to remove the climatic source of variation to assess the impacts of land management on the hydrological dynamics of agricultural landscapes. 
Following this procedure for the analysis of LWB within a Pampean agricultural basin of Argentina, our results suggest that during the last decade at least $12 \%$ of its LWB showed steadily changes in their areas due to non-climatic factors. Therefore, strong evidences were obtained about the linkage between these changes and land use impacts.

Wetland loss and degradation might be caused by both, direct and indirect impacts (Moser and others 1996). In agricultural areas, the main threats on wetlands involve outcomes from the agricultural expansion and intensification processes, such as large-scale changes in the land uses, the alteration of the watercourses through channelization and rectification, and the drainage of wetlands (Zedler and Kercher 2005). While the development of transparent, flexible models of ecological production functions at scales relevant to decision making has become an essential task (Daily and others 2009), the possible outcomes of changes in the vegetal cover, expected to alter the regional hydrology, are not well known (Jobbágy 2011). Here, at least for the study area, a strong direct relationship between grasslands loss and the alteration of LWB was found (Figs. 6, 7). In fact, the presence of altered LWB in the watersheds as a function of the degree of grasslands replacement can be considered an evidence of the hydrologic regulation service provided by grasslands. In this sense, the applied methodology might contribute to the estimation of the supply of this ecosystem service by grasslands at the large-scale, usually estimated through the transference of economic or arbitrary values per unit area (i.e., Costanza and others 1997; Troy and Wilson 2006) or through the utilization of proxies like the "infiltration" (Nelson and others 2009) and the contribution of groundwater to base flows (Egoh and others 2008).

Little attention has been paid to the hydrological impacts of the transitions between similar vegetation types, such as from grasslands to sown pastures or annual crops (Nosetto and others 2012). In the plains, these transitions can play an important role by promoting water excess and flooding. Crops usually have higher rates of evapotranspiration than sown pastures, and these than natural grasslands. However, the frequency of vegetation inactivity increases in the order grasslands-sown pastures-crops. As a result, annual and multiannual water balance (precipitation/ evapotranspiration) may become more positive in the order grassland-sown pasture-annual crop, and stimulate the water excess in some areas (Viglizzo and others 2009). The predominance of one or another process under certain circumstances might be the reason why the number of both types of altered LWB (increasing and decreasing ones) are positively related with the grassland and sown pastures replacements. Being able to predict the predominant process undoubtedly requires further studies. Thus, the replacement of grasslands by sown pastures, and the replacement of pastures by crop fields can cause significant changes in the regional hydrology within a decade.

The degree of modification of the Mar Chiquita basin is alarming: almost two hundred small LWB (area $<1,800 \mathrm{~m}^{2}$ ), have been traversed by channels in order to be drained, and $17 \%$ of the streams have been already channelized. Even though these disturbances were not related to the number of altered LWB per basin within the study period, some of these works may predate 1998, and thus earlier effects on surface water bodies cannot be discarded. Moreover, the decreasing area of two of the largest wetlands in the basin, Los Talitas and Mar Chiquita lagoon, might be related to these impacts, as both wetlands are located downstream of most of the works and drained wetlands.

Although the smaller LWB were out of the reach of this study because of its resolution constraint, the impact of land use changes on their areas and densities should not be neglected. For example, it has been suggested that a large number of small wetlands may have a greater filter effect than a small number of large wetlands covering the same area, because in the first case the chances of intercepting the runoff flow are increased (Booman and others 2010). Also, several stream functions as water regulation, nutrient cycling and erosion control are negatively affected by their channelization and straightening (Schoof 1980; Brooker 1985). Future studies should attempt to assess the outcomes from engineering works associated with agricultural development, and the effects of the loss of small wetlands that are beyond the resolution of the images used here, but might have ecological functions with a significant effect at the landscape scale.

In brief, a new methodology for the assessment of nonclimatic changes of lentic surface water bodies and the identification of the land use changes that cause them was developed and is hereby presented. It is also shown that the grasslands reduction can cause a noticeable loss of hydrological regulation at the catchment scale within a decade.

Acknowledgments This research was supported by the National Agency of Scientific and Technological Promotion (FONCYT, Argentina), the National University of Mar del Plata (UNMdP), and the National Institute of Agricultural Technnology of Argentina (INTA). We thank Laura Giménez from INTA Corrientes, whose assessment in statistics was crucial for the simultaneous analysis of the 3,689 LWB. Also, we thank Dr. Marino Puricelli from INTA Balcarce, for hydrological assessment and ideas, and Ing. Karina Zelaya for sharing basic information of land use in the study area.

\section{References}

Booman GC, Orúe ME, Laterra P (2010) Valoración de los humedales como filtros ecológicos para la identificación de áreas vulnerables a la contaminación difusa de aguas superficiales. Estudio de caso: la Cuenca Mar Chiquita (Prov. de Bs As). In: Hacia la Gestión Integral de los Recursos Hídricos en Zonas de Llanura 
Proceedings of the First International Congress on Hydrology of the Plains, Azul, Buenos Aires, Argentina

Bridgham SD, Megonigal JP, Keller JK, Bliss NB, Trettin C (2006) The carbon balance of North American wetlands. Wetlands 26:889-916

Brooker MP (1985) The ecological effects of channelization. The Geographical Journal 151:63-69

Chander G, Markham BL, Helder DL (2009) Summary of current radiometric calibration coefficients for Landsat MSS, TM, ETM+, and EO-1 ALI sensors. Remote Sensing of Environment 113(5):893-903

Costanza R, d'Arge R, De Groot R, Farber S, Grasso M, Hannon B, Limburg K, Naeem S, O’Neill RV, Paruelo J (1997) The value of the world's ecosystem services and natural capital. Nature 387:253-260

Daily GC, Polasky S, Goldstein J, Kareiva PM, Mooney HA, Pejchar L, Ricketts TH, Salzman J, Shallenberger R (2009) Ecosystem services in decision making: time to deliver. Frontiers in Ecology and the Environment 7:21-28

Egoh B, Reyers B, Rouget M, Richardson DM, Le Maitre DC, van Jaarsveld AS (2008) Mapping ecosystem services for planning and management. Agriculture, Ecosystems \& Environment 127:135-140

Finlayson CM, Rea N (1999) Reasons for the loss and degradation of Australian wetlands. Wetlands Ecology and Management 7:1-11

Gerakis A, Kalburtji K (1998) Agricultural activities affecting the functions and values of Ramsar wetland sites of Greece. Agriculture, Ecosystems \& Environment 70:119-128

Jarvis A, Reuter HI, Nelson A, Guevara E (2008) Hole-filled SRTM for the globe Version 4, available from the CGIAR-CSI SRTM 90m Database (http://srtm.csi.cgiar.org). Accessed 14 Jan 2011

Jensen JR, Qiu F, Patterson K (2001) A neural network image interpretation system to extract rural and urban land use and land cover information from remote sensor data. Geocarto International 16:1-10

Jobbágy EG (2011) Servicios Hídricos de los ecosistemas y su relación con el uso de la tierra en la llanura chaco-pampeana. In: Laterra P (Ed.) Valoración de Servicios Ecosistémicos Conceptos, herramientas y aplicaciones para el ordenamiento territorial. Ediciones INTA, pp 163-183

Kandus P, Minotti P, Malvárez AI (2008) Distribution of wetlands in Argentina estimated from soil charts. Acta Scientiarum, 30 (4): 403-409. Brasil, ISSN 1415-6814

Keddy PA (2010) Wetland ecology: principles and conservation. Cambridge University Press, New York

Liu J, Tian H, Liu M, Zhuang D, Melillo JM, Zhang Z (2005) China's changing landscape during the 1990s: Large-scale land transformations estimated with satellite data. Geophysical Research Letters 32:1-5

Mitsch WJ, Gosselink JG (2000) The value of wetlands: importance of scale and landscape setting. Ecological Economics 35:25-33

Moser M, Prentice C, Frazier S (1996) A global overview of wetland loss and degradation. In: Wetlands International Presented to
Technical Session B of the 6th Meeting of the Conference of the Contracting Parties in Brisbane, Australia

NASA (2009) Landsat 7 Science Data User's Handbook. Landsat Project Science Office, NASA Goddard Space Flight Science Center Available at: http://landsathandbook.gsfc.nasa.gov/handbook/hand book toc.html

Nelson E, Mendoza G, Regetz J, Polasky S, Tallis H, Cameron DR, Chan KMA, Daily GC, Goldstein J, Kareiva PM et al (2009) Modeling multiple ecosystem services, biodiversity conservation, commodity production, and tradeoffs at landscape scales. Frontiers in Ecology and the Environment 7:4-11

Nosetto MD, Jobbágy EG, Brizuela AB, Jackson RB (2012) The hydrologic consequences of land cover change in central Argentina. Agricultural, Ecosystems and Environment 154:2-11

Quirós R, Boveri MB, Petracchi CA, Rennella AM, Rosso JJ, Sosnovsky A, von Bernard HT (2006) Los efectos de la agriculturización del humedal pampeano sobre la eutrifización de sus lagunas, pp 1-16

Rebelo LM, Finlayson CM, Nagabhatla N (2009) Remote sensing and GIS for wetland inventory, mapping and change analysis. Journal of Environmental Management 90:2144-2153

Schoof R (1980) Envirnonmental impact of channel modification. Journal of the American Water Resources Association 16:697-701

Soriano A (1992) Rio de la Plata grasslands. In: Coupland RT (ed) Ecosystems of the world 8A. Natural grasslands. Introduction and western hemisphere. Elsevier, New York, pp 367-407

Troy A, Wilson MA (2006) Mapping ecosystem services: practical challenges and opportunities in linking GIS and value transfer. Ecological Economics 60:435-449

Viglizzo EF, Frank FC, Carreño L (2006) Situación ambiental en las ecorregiones Pampa y Campos Malezales. In: Brown A, Ortíz UM, Acerbi M, Corcuera J (eds) La situación Ambiental Argentina 2005. Fundación Vida Silvestre Argentina, Buenos Aires

Viglizzo EF, Jobbagy EG, Carreño LV, Frank FC, Aragón R (2009) The dynamics of cultivation and floods in arable lands of central Argentina. Hydrology and Earth System Science 13:491-502

WCMC (1992) Global biodiversity: status of the Earth's living resources. Chapman and Hall, London, p 594

Zedler JB (2003) Wetlands at your service: reducing impacts of agriculture at the watershed scale. Frontiers in Ecology and the Environment 1:65-72

Zedler JB, Kercher S (2005) Wetland resources: status, trends, ecosystem services, and restorability. Annual Review of Environment and Resources 30:39

Zelaya DK, Maceira NO (2007) Avance de la Agricultura en la Cuenca Hidrológica de Mar Chiquita, Región Pampeana Argentina. In: XII Congreso de la Asociación Española de Teledetección, Mar del Plata, Argentina

Zhang J, Ma K, Fu B (2010) Wetland loss under the impact of agricultural development in the Sanjiang Plain, NE China. Environmental Monitoring and Assessment 166:139-148 